\title{
Fruits From the Higher Branches of Learning: The Future of Bringing Research Into the Classroom
}

\author{
Thomas F. Connolly \\ Prince Mohammad Bin Fahd University
}

Connecting esoteric research to mundane classroom material seems daunting. Yet, it is a myth that diligent scholars cannot be effective teachers, or that students will not be interested in what professors are working on. On the contrary, students will be engaged with professors who share when it is done with élan. Showing the practical application of research in the classroom is a significant way to energize both the students and the curriculum. However, it is a myth that scholars cannot be effective teachers. Students engage with professors' research as long as it is done with élan. The practical application of research in the classroom energizes students and curricula. Over two millennia ago, Socrates chastised Phaedrus for being bewitched by the new learning technology of the text. The argument over this issue is driven by contradictory evidence. The controversy mirrors the overstated claims of big data enthusiasts and reflects the industrial model's threat to education. This paper argues that a future integrated scholarly and teaching community must be fostered by universities.

Keywords: research, pedagogy, classroom technology, quantification, assessment, scholarly community, student evaluations, rankings, scientific management, industrial education model

It is a myth that scholars cannot be effective teachers. Students engage with professors' research when it is done with élan. The application of research in the classroom energizes students and curricula. However, the argument over this issue is driven by contradictory evidence. The controversy mirrors the overstated claims of big data enthusiasts and reflects the industrial model's threat to education. Scientific management is not a viable approach, given that the foundational work of Frederick Winslow Taylor has been exposed as at best dubious and at worst, fraudulent. Great teaching has always denied technology any salvific function. While it remains one of the great ironies that Plato recorded Socrates's distrust of the written word as a means of disseminating knowledge, this signal skepticism from the dawn of pedagogy should inform our discourse today. Scholars sharing their research and involving their students directly with these inquiries provide the opportunities for profundity. This paper argues that an integrated scholarly and teaching community must be fostered by universities.

Connecting seemingly esoteric research to mundane classroom material sometimes seems daunting. A recent study by the Brookings Institute argues that it is erroneous to assume empirical differences between scholarship and pedagogical wonder (Figlio D. and Schapiro M. (2017). An American Council of Learned Societies white paper on student learning and faculty research argues: "students are more likely to perceive benefits related to faculty research when institutions actively manage a balance or integration between research and teaching" (Byerly, A., Chang, M. J. et al., 2007). 
The research though is contradictory and inconclusive. The Brookings Institute attempts to smash down the entire concept that research and teaching correlate, while the American Council of Learned Societies earnestly argues that the two are vitally connected. The data proffered by the Brookings Institute and the research cited by the ACLS seemingly cancels one another out. The frame for both inquiries though is so broad that one must question the premise of each study. They are attempting to somehow quantify teaching and algorithmically solve the question of learning outcomes.

There is a larger issue here: the romance of big data and the chimera of number crunching. The quixotic obsession with quantification reduces measurement to that which can be measured. It all seems to boil down to averaging. Does a roster with grades at semester's end sum up the term's accomplishments? No one would admit to this - yet it is variations on this data set that seem to be the determiner for academic judgments. A worse indicator is the "scoring" system for student evaluations of teaching. Most evaluation forms include space for students to write comments, but comments cannot be tallied, cannot be quantified. At an American university where I was teaching, I once requested that my students ignore the standardized portions of the evaluation and only write comments. I was told that my classes had failed to submit proper forms. This was not the case when students only filled in the ovals and did not write any comments. Forms that could not be scanned did not exist. A highly cited article by Goos and Salomons questions the validity of student evaluations on many levels, not the least of which is their statistical illegitimacy. At the basic level of sampling, the number of students who respond is so low that the collected data are practically meaningless. As their review of the literature demonstrates, this article is not the first to challenge the efficacy of student evaluations as a pedagogical assessment (Goos and Salomons, 2017).

Such data chasing is symptomatic of the replacement of the artisanal model of education with the industrial one. The industrial model that pervades education today has created the bizarre situation where "creativity courses" are demanded by the business schools of universities (Morgan and Nelligan, 2018). Arts instructors, desperate to hold on to their jobs, twist themselves to format a curriculum out of thin air. They make presentations at faculty committees and assemblies, bolstered by a burgeoning literature, which insists that creativity can be taught and how it is a vital marketable skill, etc. (Pappano, 2014). Often "creativity" is teamed with "innovation" (Anderson, Potočnik, and Zhou 2014). People have convinced themselves that innovation can be somehow channeled into the product of a syllabus. Whereas, anyone who attends university faculty assemblies regularly knows that "creativity and innovation" is only the most recent "revolution" in pedagogy to emerge from business schools (Govindarajan, V. (2010). Every four or five years, comes a new demand from management faculty that the latest gewgaw of which management consultants are suddenly enamored must be adopted at once (Selwyn 2016), else future graduates will be forever unemployable or the university will be branded as out of date as schools of elocution and oratory. A few years ago, "team-building" or "cohorting" was all the rage. Eleven years ago, a university without required courses in team building might as well have been prescribing courses in scanning Homeric verse. There is an endless game of management theory catch-up going on. (Petriglieri, 2020).

It never seems to matter that anyone with a memory can remind the enthusiasts that only a few semesters ago, yet another formula guaranteeing "real world" success was being peddled. The desperate faith that this "new" method is going to clinch the deal persists. Matthew Stewart argues,

Why does every new management theorist seem to want to outdo Chairman Mao in calling for perpetual havoc on the old order? Very simply, because all economic organizations involve at least some degree of power, and power always pisses people off. That is the human condition. At the end of the day, it isn't a new world order that the management theorists are after; it's the sensation of the revolutionary moment. They long for that exhilarating instant when they're fighting the good fight and imagining a future utopia. What happens after the revolution - civil war and Stalinism being good bets - could not be of less concern. Between them, Taylor and Mayo carved up the world of management theory. According to my scientific sampling, you can save yourself from reading about 99 percent of all the management literature once you master this dialectic between rationalists and humanists. The Taylorite rationalist says: Be efficient! The Mayo-ist humanist replies: 
Hey, these are people we're talking about! And the debate goes on. Ultimately, it's just another installment in the ongoing saga of reason and passion, of the individual and the group (Stewart, 2006).

How can anyone take "scientific management" seriously when any literate person knows that Frederick Winslow Taylor was a charlatan who at worse faked, and at best fudged his "data" (Wrege and Perroni, 2017)? Yet his ideas beleaguered education for decades, breached its walls, and now occupy it. Career training is now the "outcome" demanded of degree programs - or is it the "goal"? Quick-what is the difference between a "goal" and an "outcome"? No two Ed.Ds will give the same flash answer. The DePaul University course guidelines offer the following,

These terms are often used interchangeably and they are all related to the teaching and learning that is expected to take place in the classroom. However, the difference between goals or objectives and outcomes lies in the emphasis on who will be performing the activities. (DePaul University, 2021).

Nevertheless, in thrall to the Department of Education, there are programs that have devised a rigid bifurcation of the terms and insist that syllabi explain in detail the difference between "goals" and "outcomes" for a given course.

In the middle of the $20^{\text {th }}$ century, Gilbert Highet, a classical scholar and professor at Columbia University wrote The Art of Teaching, in the preface he argues, "Teaching is an art, not a science. It seems... very dangerous to apply the aims and methods of science to human beings as individuals. ...'Scientific' teaching, even of scientific subjects, will be inadequate as long as both teachers and pupils are human beings" (Highet, 1950, p. vii-viii).

Later he insists, "Teaching is inseparable from learning" (Highet 1950, p. 13). Even an introductory course must be informed by the more advanced aspects of the subject. The course material must not be limited by the classroom. The syllabus is not the curriculum, nor indeed can a curriculum's dictates insure that anything has been learned. Anyone with experience in a classroom knows that the closer an administrator insists on adherence to a set rubric, the less that person knows about teaching. "A limited field of material stirs very few imaginations" (Highet 1950, p. 14). An instructor must focus not on the wretched limitations of slotted "outcomes," but on the expanding realm of the classroom. I might add that though Highet flourished over seventy years ago, his influence touches living memory. A couple of years ago, I referred to another of Highet's books, The Classical Tradition, in an introductory drama class. We were having a lecture by visiting professor Robert Brustein, of Harvard, America's most distinguished drama critic, his face lit up when I mentioned Highet. He exclaimed joyfully, "My old professor!" Let us be clear, Highet may have been a classicist, but he makes no brief solely for the humanities. He has no specific audience in mind-he addresses all teachers and students.

A serious and committed teacher prepares by researching, by "keeping up with the field." This is necessary to keep our lectures and discussion leading alive. Highet advises, "...the world changes, and scholarship must change with it; and teachers change, and their teaching must change with them" (Highet, 1950, p. 91). On a practical level, dropping hints about insights gained from one's research shows students that this moment in the classroom is only the beginning.

The enemies of erudition are all around us. Catastrophically, the education industrialists have put on the lion's skin, and brayed so long and loud that they have convinced the public that theirs is the roar of efficient progress. Anyone who raises their voices to question standardization as the be-all and end-all is likely to be dismissed as an obscurantist crank. As noted, quantifying measures only what can be measured and this is not only limiting, but also misleading. A man eats a hot dog in six bites; a woman has six bites of foie gras. Each masticated similarly. Who would argue they had the same experience?

Remember Goodhart's Law: once a useful number becomes a measure of success, it ceases to be a useful number. Recall the economist James Gustave Speth's pronouncement: "We tend to get what we measure, so we should measure what we want." Today the obsession with big data threatens to control 
things rather than helping us to understand them, (Fry, 2021, p. 71). Recently in a review of two books about data and statistics usage, Hannah Fry offers the example of using Gross Domestic Product as a metric for the success of an educational system. Doing so would show that a teacher would do better to assault a student and be committed to a high-security prison than to educate the student; as such imprisonment would sustain a large number of jobs. Note that Fry is a mathematician.

So now in the $21^{\text {st }}$ century academic arena - currently an online arena - can one use one's research in the undergraduate classroom? It is not a complicated question. Nevertheless, the educational industrialists would make it complicated. Seduced by digitized instruction, they dismiss humane teaching. Machine learning is not a term intended for the education of human beings. Professors burdened with ever more elaborate software programs that purport to quantify the learning experience have greater difficulty engaging with students who are becoming education consumption units and less time to pursue research, What is worse, the inflation of rankings impels professors to publish as much as possible. Humanities scholars are hobbled by both the normal length of papers in the fields and the long vetting process. Traditionally, humanities scholars were expected to publish books of which there was ideally one author, but these have no "impact factor." Scientists and engineers frequently collaborate and can publish papers of only a few pages, but the maw of quantification can sense no difference (Hammarfelt and Haddow, 2018).

To bring one's research into the classroom-even the 100 level class-requires the sharing of experience, even the sharing of enthusiasm. I have been a university instructor for 35 years- $\mathrm{I}$ am not talking about cheerleading for Shakespeare's sonnets or solving Fermat's last theorem. I mean revealing the growth that occurs while seeking knowledge. Many students are intrigued by the words, "An article I'm writing", "A book I just finished writing", or even "In a paper I gave recently..." This instantly conveys authority. Professors who have invited their classes when they have given papers or a public lecture almost always discover students in attendance.

Recently though, technology has begun its long-threatened onslaught on the soul of education and many education industrialists are delighted by the prospect of providing education at minimal cost with maximal profit. The artisanal model of teacher and student is in danger. Ironically, the piece of evidence frequently cited for the necessity of "on-line learning" is the "fact" that the last technological innovation in education was the printing press. We can only hope that the sudden, enforced adoption of online classrooms will give Bill Gates's acolytes pause (Harvard Center for Education Policy Research, 2019). Those in the arts and sciences must recognize that the sharing of research is what matters, not the accumulation of points toward some chimerical impact factor (Paulus, Cruz, and Krach, 2018). Too many academics though, have been complicit in the breakdown of the artisanal model and its replacement with the industrial model. Rankings pressure professors to produce assembly-line style research. The proliferation of for-profit academic publishers enables this. It is a cruel irony that open-access publishing has exacerbated the problem by increasing the number of journals that charge for publication. They justify this by claiming their expenses are not subsidized by a scholarly society or a university. Predatory publishing has become a scourge. Moreover, this may have created a barrier between the sharing of experience in the classroom as the research is undertaken to produce rather than to be part of genuine inquiry or discovery.

What is at the heart of what used to be called the "liberal arts"? I say, "used to" because so many colleges and universities so fear the adjective "liberal" they have retitled this division of their curriculum: "Arts," as in "College of Arts and Sciences." Reading and writing are the heart of this program of study, that is to say, literature.

Consider what one short poem can do. The German poet Rilke wrote a sonnet whose final line: "You must change your life" embodies the power of literature (Rilke, 1908). Even limiting this to Wolfgang Iser's transactional level, Rilke's sonnet, "Archaic Torso of Apollo" calls for an imaginative exchange between text and reader (Iser, 1978, p. 24). This would seem to sum up what the humanities are supposed to doeven if one regards "text" as something more than something on a page: as a statue for instance. Nevertheless, the statue inspired the poem; it is not the poem itself. This reminds the reader that Keats' Grecian urn speaks the famous lines about truth and beauty, not the poet himself. Regarding another of Keats' odes, the poet wrote a letter to his friend explaining how he came to write his poem, "To Autumn" 
(Keats, 1819, p. 492-494). The stubble-field that inspired Keats was not a text; it was a patch of ground. The poem is the text. Yet this expansion of definition or categorization is also something of a problem for it implies that reading and seeing or listening, indeed employing any of the senses in an intellectual pursuit, may be essentially the same process. What is more, that one's application of intellectual skills is equally well employed defining Odysseus's or Spiderman's heroics. This is representative of how critical theory's discussions of literature have drifted so far from the "Common Reader's" consciousness as to almost be in a different language. It shares something with the mining of big data: total dependence on jargon and received ideas. However, to introduce such a problem into an introductory class in composition is exactly how the classroom can be expanded. One can bring up Rilke's statue or Keats' field not only as literary problems, but also as issues of perception, which are universal questions.

Today, search engine optimization (SEO) is the order of the day, and key word searchability trumps profundity. Buzz threatens to overwhelm scholarly debate.

We can overcome this by sticking to first principles--our calling that ordains us as teachers and scholars. Let us strive always to use academic research as part of teaching as many students as possible, even beyond the classroom. Not as something to jack up percentiles, inflate impact factors, or perpetuate any other algorithmic rigmarole. Universities must return to fostering an integrated scholarly and teaching community.

Over twenty-four hundred years ago, Socrates warned against zealously accepting new technology as a teaching tool,

For this invention will produce forgetfulness in the minds of those who learn to use it, because they will not practice their memory. Their trust in writing, produced by external characters which are no part of themselves, will discourage the use of their own memory within them. You have invented an elixir not of memory, but of reminding; and you offer your pupils the appearance of wisdom, not true wisdom, for they will read many things without instruction and will therefore seem to know many things, when they are for the most part ignorant and hard to get along with, since they are not wise, but only appear wise (Harvard University 1904, 1999).

Of course, no one advocates a return to exclusively oral learning. Yet the things that Socrates emphasizes are startlingly relevant to the debate over online learning. In this paper, I have put forward caveats about the industrial model of education, the rush to quantify, and that the scholar-teacher is the ideal pedagogical model for higher learning. Socrates chastises Phaedrus for presenting the "appearance of wisdom" to his students. Two millennia later, we are in danger of allowing ourselves to elide the "input of data" into research, teaching, and learning. Our universities must provide genuine learning solutions, not technological "elixirs." To insure this, faculty must be encouraged to do research that facilitates learning in the classroom and generates public discussion, not push percentage points on a rankings table. Our educational future must be grounded in applying the traditions of the past. As it always has before, new research will engender adaptive pedagogy. In terms of tomorrow, we must not allow the tools themselves to supersede the text.

\section{ACKNOWLEDGEMENTS}

A grant from the Prince Mohammad Bin Fahd Center for Futuristic Studies at Prince Mohammad Bin Fahd University (PMFCFS) and the World Futures Studies Federation (WFSF) supported the research for this article.

\section{REFERENCES}

Anderson, N., Potočnik, K., \& Zhou, J. (2014, March). Innovation and Creativity in Organizations: A State-of-the-Science Review, Prospective Commentary, and Guiding Framework. Journal of Management. Retrieved from https://journals.sagepub.com/doi/10.1177/0149206314527128 
Byerly, A., Chang, M.J., Chopp, R., Fix, S., Jaquette, J.S., Kuh, G.D., . . ACLS Staff. (2007). ScholarTeachers and Student Learning. ACLS Teagle Working Group in Liberal Education. Retrieved from https://1library.net/document/y87v745z-student-learning-faculty-research-connectingteaching-scholarship-foundation.html

Course Objectives \& Learning Outcomes. (2012). Retrieved from https://resources.depaul.edu/teachingcommons/teaching-guides/course-design/Pages/course-objectives-learning-outcomes.aspx

Figlio D., \& Schapiro M. (2017). Are Great Teachers Poor Scholars? Brookings Institute Evidence Speaks Reports, 2(6). Retrieved from https://www.brookings.edu/research/are-great-teachers-poorscholars/

Fry, H. (2021, March 29). What Really Counts. The New Yorker, pp. 70-74.

Goos, M., \& Salomons, A. (2017). Measuring Teaching Quality in Higher Education: Assessing Selection Bias in Course Evaluations. Research in Higher Education, 58, 341-364. DOI 10.1007/s11162016-9429-8

Govindarajan, V. (2010, August). Innovation is Not Creativity. Harvard Business Review. Retrieved from https://hbr.org/2010/08/innovation-is-not-creativity.html

Hammarfelt, B., \& Haddow G. (2018). Conflicting Measures and Values: How Humanities Scholars in Australia and Sweden Use and React to Bibliometric Indicators. The Journal of the Association for Information Science and Technology, 69(7), 924-935. https://doi.org/10.1002/asi.

Harvard Center for Educational Policy. (2019). The Gates Foundation is hoping better curriculum will boost student learning. A new study says, not so fast. Retrieved from https://cepr.harvard.edu/news/gates-foundation-hoping-better-curriculum-will-boost-studentlearning-new-study-says-not

Highet, G. (1950). The Art of Teaching. New York: Knopf.

Highet, G. (1949). The Classical Tradition; Greek and Roman Influences on Western Literature. Oxford: Clarendon Press.

Iser, W. (1978). The Act of Reading: A Theory of Aesthetic Response. Baltimore and London: Johns Hopkins University Press, 24ff.

Keats, J. (1819, 1990, September 21). Letter to J. H. Reynolds. 21 September. Reprinted in E. Cook (Ed.), John Keats: A Critical Edition of the Major Works. Oxford University Press.

Morgan, G., \& Nelligan, P. (2018). The Creativity Hoax: Precarious Work and the Gig Economy. Anthem Press.

Pappano, L. (2014, February 9). Learning to Think Outside the Box. The New York Times. Retrieved from https://www.nytimes.com/2014/02/09/education/edlife/creativity-becomes-an-academicdiscipline.html

Paulus, F.M., Cruz, N., \& Krach, S. (2018). The Impact Factor Fallacy. Frontiers in Psychology, 9, Article 1487. https://doi.org/10.3389/fpsyg.2018.01487

Plato. (1904, 1996). "Phaedrus," Plato in Twelve Volumes (Vol. 9), translated by Harold N. Fowler. Cambridge, MA, Harvard University Press. Retrieved from http://www.perseus.tufts.edu/hopper/text?doc=Perseus:text:1999.01.0174

Petriglieri, G. (2020, June). Are Our Management Theories Outdated? Harvard Business Review. Retrieved from https://hbr.org/2020/06/are-our-management-theories-outdated

Rilke, R.M. (1908, 1995). Archaic Torso of Apollo. Translated by S. Mitchell. Retrieved from https://poets.org/text/archaic-torso-apollo

Selwyn, N. (2016). Minding our Language: Why Education and Technology is Full of Bullshit ... and What Might be done about it. Learning, Media and Technology, 41(3), 437-443.

DOI: 10.1080/17439884.2015.1012523

Stewart, M. (2006, June). The Management Myth. The Atlantic. Retrieved from https:/www.theatlantic.com/magazine/archive/2006/06/the-management-myth/304883/

Wrege, C.D., \& Perroni A.G. (2017). Taylor's Pig-Tale: A Historical Analysis of Frederick W. Taylor's Pig-iron Experiments. Academy of Management Journal, 17(1). https://doi.org/10.5465/254767 